\title{
Review
}

\section{The diagnostic and prognostic role of amino-terminal pro-brain type natriuretic peptides in pediatric cardiac diseases and pulmonary hypertension}

\author{
Kayirnisa Tilemanbetova ${ }^{1}$, Taalaibek Kudaiberdiev ${ }^{1}$, Jalil Sheishenov ${ }^{2}$, Damirbek Abibillaev ${ }^{1,3}$ \\ ${ }^{1}$ Scientific-Research Institute of Heart Surgery and Organ Transplantation, Bishkek, Kyrgyzstan \\ ${ }^{2}$ National Center of Cardiac Surgery and Transplantation, Taraz, Kazakhstan \\ ${ }^{3}$ Medical Faculty, International Ala-Too University, Bishkek, Kyrgyzstan
}

\begin{abstract}
Objective: Several studies showed that N-terminal pro-brain type natriuretic peptide (NT-pro-BNP) as the reliable marker both in diagnostic and prognostic workup of pediatric patients with congenital heart disease complicated by pulmonary hypertension. Furthermore, it has well assisted both in therapeutic and surgical management of children with congenital heart diseases. In this review, we aimed to analyze recent studies concerning the role of the NT-pro-BNP in pediatric cardiac patients with pulmonary hypertension.

Methods: PubMed, Cochrane, Science Direct and Google Scholar databases were used with the searching of the following words: "amino terminal pro brain type natriuretic peptide", "pediatric pulmonary hypertension", "congenital heart diseases", emphasizing on original research articles published within recent 15 years and in English language. We critically analyzed and summarized the retrieved studies.

Conclusion: NT-pro-BNP remains as the reliable diagnostic and prognostic marker of pulmonary hypertension and congenital heart diseases in pediatric patients. NT-pro-BNP and BNP remain as the universal marker of cardiovascular pathology in pediatric population. Improvement of their effectiveness in diagnostic workup in patients with $\mathrm{CHD}$ and $\mathrm{PH}$ undergoing surgery needs further clarification.
\end{abstract}

Key words: pediatric pulmonary hypertension, $\mathrm{N}$-terminal pro brain type natriuretic peptide, congenital heart disease

(Heart Vessels Transplant 2021; 5; 21-26; doi: 10.24969/hvt.2020.244)

\section{Introduction}

Natriuretic peptides are hormonal molecules produced in cardiac chambers in response to myocardial wall stretching during pressure or volume load. In physiological circumstances, these molecules maintain homeostasis of the cardiovascular system. The natriuretic peptides produced by ventricles, or brain type peptides have been used widely in clinical medicine, due probably to longer half-lives compared to atrial peptides (1).

Basically, any cardiovascular pathology or cardiac involvement of systemic disease that cause myocardial stretching easily stimulate the increased production of brain natriuretic peptides. Thus, both brain natriuretic peptide (BNP) and its product, namely amino-terminal pro-brain natriuretic peptide (NT pro-BNP) have been found as the reliable markers in the diagnostic and prognostic spectrum of many cardiovascular conditions, including congestive heart failure, congenital heart diseases (CHD) and pediatric pulmonary hypertension (PPH) (2-4).

Nonetheless, according to several evidence-based guidelines, the most rational use of natriuretic peptides has been justified for the differential diagnosis of the congestive heart failure (CHF) with established cut-off values $(2,5)$. The routine use of BNP and NT pro-BNP was not supported by guidelines in $\mathrm{CHD}$ and $\mathrm{PPH}$. Furthermore, confirmation of diagnosis or assessment of prognosis is impossible solely on the basis of these laboratory markers.

Reference ranges and cut-off values remained under the influence of several determinants, including the age, gender, body mass index, renal disease (6-9).

In pediatric cardiology, most of the data is obtained from the observational or small cohort studies in contrast to large-scale trials conducted on adult populations.

Address for Correspondence: Damirbek Abibillaev, Scientific Research Institute of Heart Surgery and Organ Transplantation, Bishkek, Kyrgyzstan, Email: kg.damir.da@gmail.com

Received: 18.11.2020 Revised: 26.01.2021 Accepted: 27.01.2021 Copyright $\odot 2021$ Heart, Vessels and Transplantation 


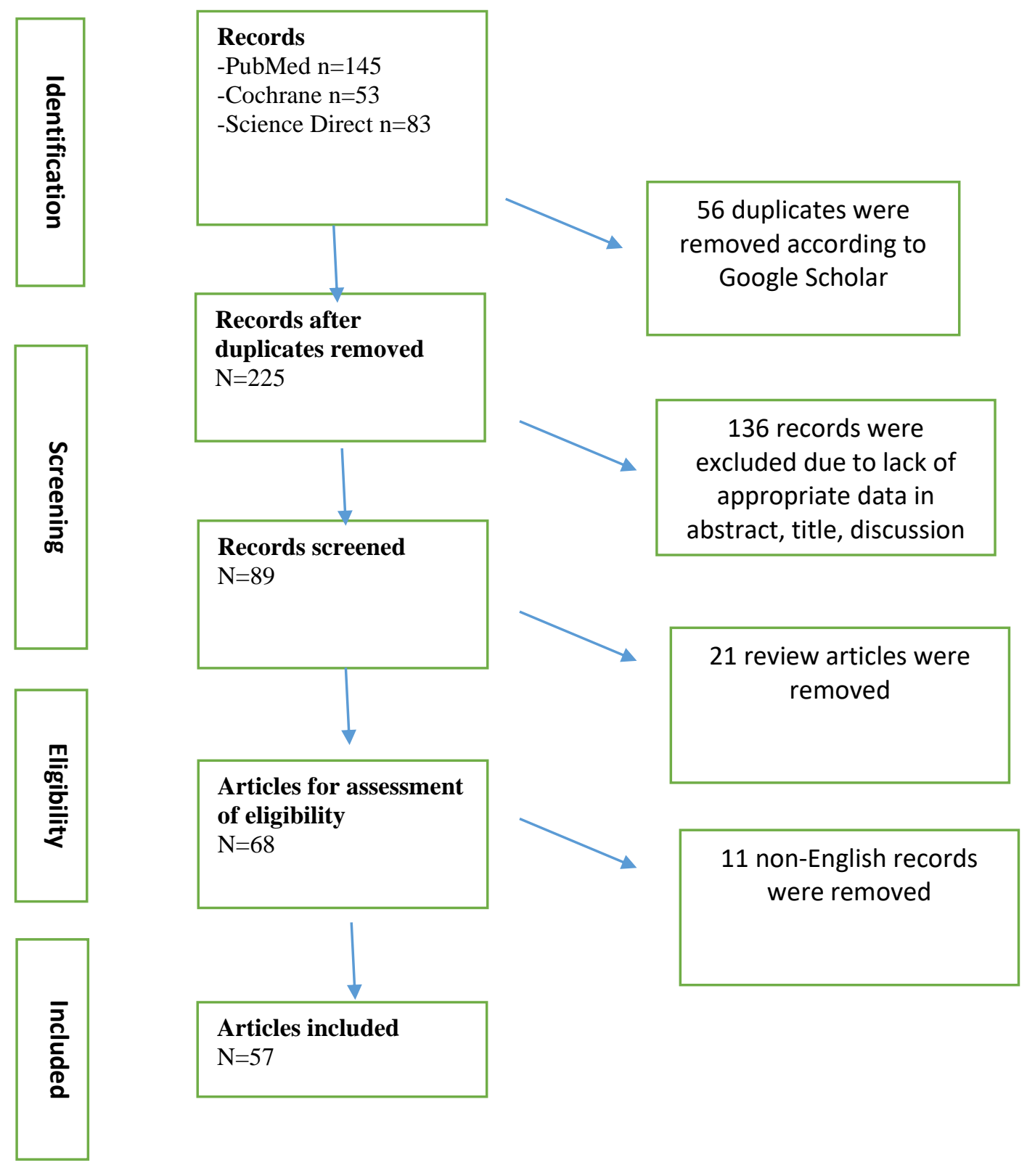

Figure 1. Flowchart of search and inclusion of studies in analysis

In this article, we aimed to review the diagnostic and prognostic roles of NT pro-BNP assay in the management of pediatric pulmonary hypertension associated with pediatric cardiovascular disorders including congenital heart diseases.

\section{Evidence search method (Fig. 1)}

PubMed, Science Direct and Cochrane library databases were searched from 2005 to 2020 for primary studies. Search terms included "pediatric pulmonary hypertension", "amino terminal natriuretic peptides", "congenital heart disease". Duplicates were removed according to Google Scholar. All study designs were included except review articles. Eligibility criteria included studies published only in English language.

The overall role of NT-pro-BNP in the pediatric cardiac disease management (Table 1)

The literature body confirmed the efficacy of BNPs in workup of children with dyspnea $(10,11)$. 
In infants, Cohen et al demonstrated the diagnostic accuracy of peptide in differential diagnosis of acute heart failure from pulmonary diseases with cut-off value of $2940 \mathrm{pg} / \mathrm{ml}$ (10). A cohort study conducted on children of 1-3 years with pneumonia accompanied by heart failure revealed the invaluable finding that NTpro-BNP is a diagnostic evaluative marker in management of patients with concomitant diseases (12).

Both BNP and NT-pro-BNP reflected the severity of heart failure, but NT-pro-BNP was found superior in correlation of modified Ross functional class of heart failure (13). Furthermore, NT-pro-BNP served as a diagnostic marker in case of cardiac involvement of pediatric non-cardiac systemic conditions, such that cystic fibrosis, thalassemia $(14,15)$.

Serial NT pro-BNP analysis was recommended as the prognostic rationale. According to Medar et al. degree of decline of NT pro-BNP in the first week was strongly associated with adverse cardiovascular events in pediatric patients with myocardial dysfunction and acute decompensated heart failure (16).

The studies conducted on adults with the objective of "NT pro-BNP guided therapy" could not reach the primary end-point, whereas in pediatric populations such kind of study was not available (17). Recently Januzzy et al. stated the exploratory results of modification of NT-pro-BNP concentration on the background of angiotension receptor-neprilysin inhibitor (ARNI) treatment in a large cohort of adults with congestive heart failure (18). Again, no rationalized approach has been proposed yet in pediatric patients. In conclusion, the pediatric heart failure is the wellstudied branch of pediatric cardiology regarding to natriuretic peptides. Still, gaps in the predictive evidence of peptides exist, especially for the "NT proBNP guided therapy" regimen.

\begin{tabular}{|c|c|c|}
\hline Authors & Age, gender, ethnicity or other specific aspects & $\begin{array}{l}\text { NT pro-BNP differentiation cut-off } \\
\text { points }\end{array}$ \\
\hline Cohen et $\mathrm{a}^{10}$ & $\begin{array}{l}\text { Differentiation of heart failure from lung } \\
\text { diseases in infants (1-36mnth) with respiratory } \\
\text { distress }\end{array}$ & $2940 \mathrm{pg} / \mathrm{ml}$ \\
\hline Rodriguez-Gonzales et al ${ }^{19}$ & $\begin{array}{l}\text { Predictor of poor outcome in children }<12 y r s \\
\text { with myocarditis }\end{array}$ & $2000 \mathrm{pg} / \mathrm{ml}$ \\
\hline Sugimoto et $\mathrm{al}^{13}$ & $\begin{array}{l}\text { Correlation of NT pro-BNP with modified Ross } \\
\text { classification }\end{array}$ & 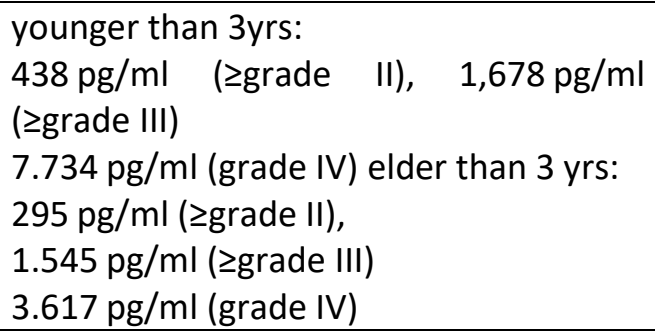 \\
\hline Jung et $\mathrm{al}^{20}$ & $\begin{array}{l}\text { Prediction of the coronary artery dilation in } \\
\text { hyperacute phase of Kawasaki disease }\end{array}$ & $515.4 \mathrm{pg} / \mathrm{mL}$ \\
\hline
\end{tabular}

\section{Congenital heart disease and NT-pro-BNP}

In adult congenital heart disease (CHD), the prognostic role of NT-pro-BNP was well investigated in contrast to pediatric population. NT-pro-BNP strongly predicted postoperative adverse events in corrected complex defects (21-23). Brain type natriuretic peptide has been found as a good prognostic marker of critical adverse events after atrial switch operations (23).
Physiologically the level of NT-pro-BNP is elevated up to several days immediately after birth, then it decreases and equals to the adult's level for whole life (3). Nevertheless, some studies revealed that, NT-proBNP was significantly elevated in infants with congenital heart diseases compared to neonates without CHD (24). 
In a relatively large cohort of pediatric patients underwent congenital heart surgery (CHS), Qu et al confirmed the predictive role of NT pro-BNP. The marker was strongly associated with prolonged duration of mechanical ventilation, intensive care unit stay and inotropic therapy within different perioperative timelines: before surgery, 1 hour, 12 hours and 36 hours after surgery (25).

Furthermore, Lin et al conducted more sophisticated analysis on children underwent $\mathrm{CHD}$ surgery by taking into account the temporal trajectory. According to them, two phenotypes of marker were distinguished: "rapidly-rising" with 5.4-fold increase in prolonged intensive care unit stay in contrast to "slowly-rising" one: (aOR=0.40, $p=0.003$ ) (26).

Our center of cardiovascular surgery recently published the study, in which potential relationships of NT pro-BNP with variety of CHD were analyzed. Due to small sample size no statistical tests were conducted. Nevertheless, higher modified Ross classes, mortality and complication rates were noted in children with NT pro-BNP level $>250 \mathrm{pg} / \mathrm{ml}$ (27).

To conclude, diagnostic and prognostic roles of natriuretic peptides in the management of congenital heart diseases are already shown. Large-scale trials are needed for development of recommendations for proper management of CHDs for daily practice of pediatric cardiologists and related specialties.

\section{NT-pro-BNP as a prognostic marker of pediatric pulmonary hypertension}

Conventionally in adults, pulmonary arterial hypertension is defined as a pulmonary arterial pressure of $\geq 25 \mathrm{~mm} \mathrm{Hg}$ at rest in the presence of normal pulmonary capillary wedge pressure $(\leq 15 \mathrm{~mm}$ $\mathrm{Hg}$ ) and increased pulmonary vascular resistance $\geq 3$ Wood Units. Due to variability in post-natal pulmonary circulation these criteria are accepted after 3 months of age in pediatric patients $(28,29)$. About $10 \%$ of CHD cases are complicated by pulmonary hypertension $(\mathrm{PH})$ and $8 \%$ by Eisenmenger syndrome $(30,31)$. According to recent guidelines, $\mathrm{PH}$ associated with CHDs is classified in several groups: septal defects with left-to-right shunts in group 1, congenital post-capillary obstructive lesions in group 2 and complex congenital anomalies in group 5 (28).

According to recent study, in a large cohort of adults NT-pro-BNP along with other two markers has been found to be additive prognostic marker of left-sided heart failure in $\mathrm{PH}$ group 1 (32).

Natriuretic peptides might be used as the prognostic markers both in therapeutic, interventional and surgical management of PH. NT-pro-BNP is also successfully used in randomized clinical trials conducted on the basis of target-therapy of $\mathrm{PH}(4,33$, 34). According to Kriechbaum et al, initially elevated NT-pro-BNP level decreased following balloon pulmonary angioplasty for inoperable chronic thromboembolic PH (35).

To sum up, NT-proBNP can be used for the diagnosis of pulmonary hypertension and as a prognostic marker in children undergoing cardiac surgery; however, to date, there are insufficient large-scale studies with heterogeneous patient groups, and diverse outcome measures.

\section{Conclusion}

NT-pro-BNP and BNP remain as the universal marker of cardiovascular pathology in pediatric population. Improvement of their effectiveness in diagnostic workup in patients with $\mathrm{CHD}$ and $\mathrm{PH}$ undergoing surgery needs further clarification.

Peer-review: External and internal Conflict of interest: None to declare Authorship: K.T., T.K., J.S., D.A. are equally contributed to article preparation

Acknowledgement and funding: None to declare

\section{References}

1.Mukoyama M, Nakao K, Saito Y, Ogawa Y, Hosoda K, Suga $S$, et al. Increased human brain natriuretic peptide in congestive heart failure. N Engl J Med 1990; 323: 757-58.

2.Yancy CW, Jessup M, Bozkurt B, Butler J, Casey DE Jr, Drazner MH, et al. 2013 ACCF/AHA guideline for the management of heart failure: a report of the American College of Cardiology Foundation/American Heart Association Task Force on practice guidelines. Circulation 2013; 128: e240-327. 
3.Cantinotti M, Law Y, Vittorini S, Crocetti M, Marco $M$, Murzi $B$, Clerico $A$. The potential and limitations of plasma BNP measurement in the diagnosis, prognosis, and management of children with heart failure due to congenital cardiac disease: an update. Heart Fail Rev 2014; 19: 727-42. doi: 10.1007/s10741-014-9422-2. PMID: 24473828.

4.Chin KM, Rubin L, Channick R, Di Scala L, Gaine S, Galiè $\mathrm{N}$, et al. Association of $\mathrm{N}$-terminal pro brain natriuretic peptide and long-term outcome in patients with pulmonary arterial hypertension. Circulation 2019; 139: 2440-50. doi: 10.1161/CIRCULATIONAHA.118.039360. PMID: 30982349; PMCID: PMC6530970.

5.Ponikowski P, Voors AA, Anker SD, Bueno $\mathrm{H}$, Cleland JG, Coats AJ, et al; Authors/Task Force Members; Document Reviewers. 2016 ESC Guidelines for the diagnosis and treatment of acute and chronic heart failure: The Task Force for the diagnosis and treatment of acute and chronic heart failure of the European Society of Cardiology (ESC). Developed with the special contribution of the Heart Failure Association (HFA) of the ESC. Eur J Heart Fail 2016; 18: 891-975. doi: 10.1002/ejhf.592. PMID: 27207191.

6. Redfield MM, Rodeheffer RJ, Jacobsen SJ, Mahoney DW, Bailey KR, Burnett JC Jr. Plasma brain natriuretic peptide concentration: impact of age and gender. J Am Coll Cardiol 2002; 40: 976-82.

7.Wang TJ, Larson MG, Levy D, Leip EP, Benjamin EJ, Wilson PW. Impact of age and sex on plasma natriuretic peptide levels in healthy adults. Am J Cardiol 2002; 90: 254-8.

8.Daniels LB, Clopton P, Bhalla V, Krishnaswamy P, Nowak RM, McCord J, et al. How obesity affects the cut-points for B-type natriuretic peptide in the diagnosis of acute heart failure. Results from the Breathing Not Properly Multinational Study. Am Heart J 2006; 151: 999-1005.

9.Anwaruddin S, Lloyd-Jones DM, Baggish A, Chen A, Krauser $D$, Tung $R$. Renal function, congestive heart failure, and amino-terminal pro-brain natriuretic peptide measurement: results from the ProBNP Investigation of Dyspnea in the Emergency Department (PRIDE) Study. J Am Coll Cardiol 2006; 47: 91-7.

10.Cohen S, Springer C, Avital A, Perles Z, Rein AJ, Argaman $Z$, et al. Amino-terminal pro-brain-type natriuretic peptide: heart or lung disease in pediatric respiratory distress? Pediatrics 2005; 115: 1347-50.
11.Sirithunyanont $\mathrm{C}$, Leowattana $\mathrm{W}$, Sukumalchantra $\mathrm{Y}$, Chaisupamonkollarp S, Watanawaroon $\mathrm{S}$, Chivatanaporn B, et al. Role of the plasma brain natriuretic peptide in differentiating patients with congestive heart failure from other diseases. J Med Assoc Thai 2003; 86 Suppl 1: S87-95.

12. Hu D, Liu Y, Tao H, Gao J. Clinical value of plasma Btype Natriuretic peptide assay in pediatric pneumonia accompanied by heart failure. Exper Therap Med 2015; 10: 2175-9.

13.Sugimoto $M$, Manabe $H$, Nakau $K$, Furuya $A$, Okushima K, Fujiyasu $\mathrm{H}$, et al. The Role of $\mathrm{N}$-Terminal pro-b-type natriuretic peptide in the diagnosis of congestive heart failure in children. J-STAGE Circulation 2010; 74: 998.

14.Welisch E, Norozi K, Rauch R. N-terminal pro-brain natriuretic peptide level as a screening tool for cardiac involvement in pediatric diseases of extracardiac origin. Clin Res Cardiol 2011: 100: 723-30.

15.Fried I, Bar-Oz B, Algur N, Fried E, Gavri S, Yatsiv I, et al. Comparison of $\mathrm{N}$-terminal pro-B-type natriuretic peptide levels in critically ill children with sepsis versus acute left ventricular dysfunction. Pediatrics 2006; 118: e1165-8.

16.Medar SS, Hsu DT, Ushay HM, Lamour JM, Cohen HW, Killinger JS. Serial Measurement of aminoterminal pro-B-type natriuretic peptide predicts adverse cardiovascular outcome in children with primary myocardial dysfunction and acute decompensated heart failure. Pediatr Crit Care Med 2015; 16: 529-34.

17.Porapakkham P, Porapakkham P, Zimmet H, Billah B, Krum H. B-Type natriuretic peptide-guided heart failure therapy: a meta-analysis. Arch Intern Med 2010; 170: 507-14.

18.Januzzi JL, Prescott MF, Butler J, Felker JM, Maiser $A S, M c C a g u e ~ K$, et al. Association of change in $\mathrm{N}$ terminal pro-B-type natriuretic peptide following initiation of sacubitril-valsartan treatment with cardiac structure and function in patients with heart failure with reduced ejection fraction. JAMA 2019; 322: 1085-95. doi:10.1001/jama.2019.12821

19.Rodriguez-Gonzalez M, Sanchez-Codez MI, LubianGutierrez M, Castellano-Martinez A. Clinical presentation and early predictors for poor outcomes in pediatric myocarditis: A retrospective study. World J Clin Cases 2019; 7: 548-61. doi: 10.12998/wjcc.v7.i5.548. PMID: 30863755; PMCID: PMC6406197. 
20. Jung JY, Ham EM, Kwon H, Kwak YH, Kim DK, Lee $\mathrm{JH}$, Jung $\mathrm{JH}$. N-terminal pro-brain natriuretic peptide and prediction of coronary artery dilatation in hyperacute phase of Kawasaki disease. Am J Emerg Med 2019; 37: 468-71. doi: 10.1016/j.ajem.2018.06.021.

21.Hegarova $M$, Brotanek J, Kubanek M, Kockova R, Franekova J, Lanska $\mathrm{V}$, et al. B-type natriuretic peptide: powerful predictor of end-stage chronic heart failure in individuals with systolic dysfunction of the systemic right ventricle. Croat Med J 2016; 57: 343-50. doi: 10.3325/cmj.2016.57.343. PMID: $27586549 ;$ PMCID: PMC5048222.

22.Popelová JR, Tomková M, Tomek J. NT-pro-BNP predicts mortality in adults with transposition of the great arteries late after Mustard or Senning correction. Cong Heart Dis 2017; 12: 448-57. doi: 10.1111/chd.12466. PMID: 28419713.

23. Haberger S, Hauser M, Braun SL, Schuster T, Ewert $\mathrm{P}$, Nagdyman N, et al. Prognostic value of plasma Btype natriuretic peptide in the long-term follow-up of patients with transposition of the great arteries with morphologic right systemic ventricle after atrial switch operation. Circ J 2015; 79: 2677-81. doi: 10.1253/circj.CJ-15-0348. PMID: 26376601.

24.Sahingozlu T, Karadas U, Eliacik K, Bakiler AR, Karadas NO, Kanik MA, et al. Brain natriuretic peptide: the reason of respiratory distress or lung disease? Am J E Med 2015: 33: 697-700.

25. Qu J, Liang H, Zhou N, Li L, Wang Y, Li J, Cui Y. Perioperative NT-proBNP level: Potential prognostic markers in children undergoing congenital heart disease surgery. J Thorac Cardiovasc Surg 2017; 154: 631-640. doi: 10.1016/j.jtcvs.2016.12.056. Epub 2017 Feb 10. PMID: 28283228.

26.Lin F, Zheng L, Cui Y, Chen W, Gupta RK, Li H, et al. Prognostic value of perioperative NT-pro-BNP after corrective surgery for pediatric congenital heart defects. BMC Pediatr 2019; 19: 497 doi: 10.1186/s12887-019-1830-y. PMID: 31842815; PMCID: PMC6913023.

27.Akhmedova IA, Kudaiberdiev TZ, Abibillaev DA, Zhooshev AA, Zaripov DE, Tilemanbetova KT, et al. Relationship of preoperative NT-pro-BNP with clinical, perioperative and prognostic markers in cardiac surgery: Preliminary study results. Heart Vessels Transp 2020: 4: 99-110. DOI: 10.24969/hvt.2020.205

28. Galiè N, Humbert $M$, Vachiery JL, Gibbs $S$, Lang I, Torbicki A, et al; ESC Scientific Document Group. 2015 ESC/ERS Guidelines for the diagnosis and treatment of pulmonary hypertension: The Joint Task Force for the Diagnosis and Treatment of Pulmonary Hypertension of the European Society of Cardiology (ESC) and the European Respiratory Society (ERS): Endorsed by: Association for European Paediatric and Congenital Cardiology (AEPC), International Society for Heart and Lung Transplantation (ISHLT). Eur Heart J 2016; 37: 67119. doi: 10.1093/eurheartj/ehv317 PMID: 26320113. 29. Rosenzweig EB, Abman SH, Adatia I, Beghetti M, Bonnet $D$, Haworth $S$, et al. Pediatric pulmonary arterial hypertension: updates on definition, classification, diagnostics and management. Eur Respir J 2019; 53: 1801916. doi: 10.1183/13993003.01916-2018. PMID: 30545978; PMCID: PMC6351335.

30.Pascall E, Tulloh RM. Pulmonary hypertension in congenital heart disease. Future Cardiol 2018; 14: 343-53. doi: 10.2217/fca-2017-0065. PMID: 29792339; PMCID: PMC6136120.

31.Daliento L, Somerville J, Presbitero P, Menti L, Brach-Prever, Rizzoli G, et al. Eisenmenger syndrome. Factors relating to deterioration and death. Eur Heart J 1998; 12: 1845-55.

32.Simpson CE, Damico RL, Hassoun PM, Martin LU, Yung J, Nies $M$, et al. Noninvasive prognostic biomarkers for left-sided heart failure as predictors of survival in pulmonary arterial hypertension. Chest 2020: 157: 1606-16.

33.Rosenkranz S, Ghofrani H, Beghetti $M$, et al. Riociguat for pulmonary arterial hypertension associated with congenital heart disease. Heart 2015; 101: 1792-9.

34.Galiè $N$, Jansa $P$, Pulido $T$, Channick RN, Delcroix $M$, Ghofrani H-A, et al. SERAPHIN hemodynamic substudy: the effect of the dual endothelin receptor antagonist macitentan on haemodynamic parameters and NT-pro-BNP levels and their association with disease progression in patients with pulmonary arterial hypertension. Eur Heart J 2017; 38: 1147-55. 35. Kriechbaum SD, Wiedenroth CB, Walter JS, Hutz R, Haas $\mathrm{M}$, Breithecker $\mathrm{A}$, et al. $\mathrm{N}$-terminal pro-B-type natriuretic peptide for monitoring after balloon pulmonary angioplasty for chronic thromboembolic pulmonary hypertension. J Heart Lung Transplant 2018; 37: 639-46. 


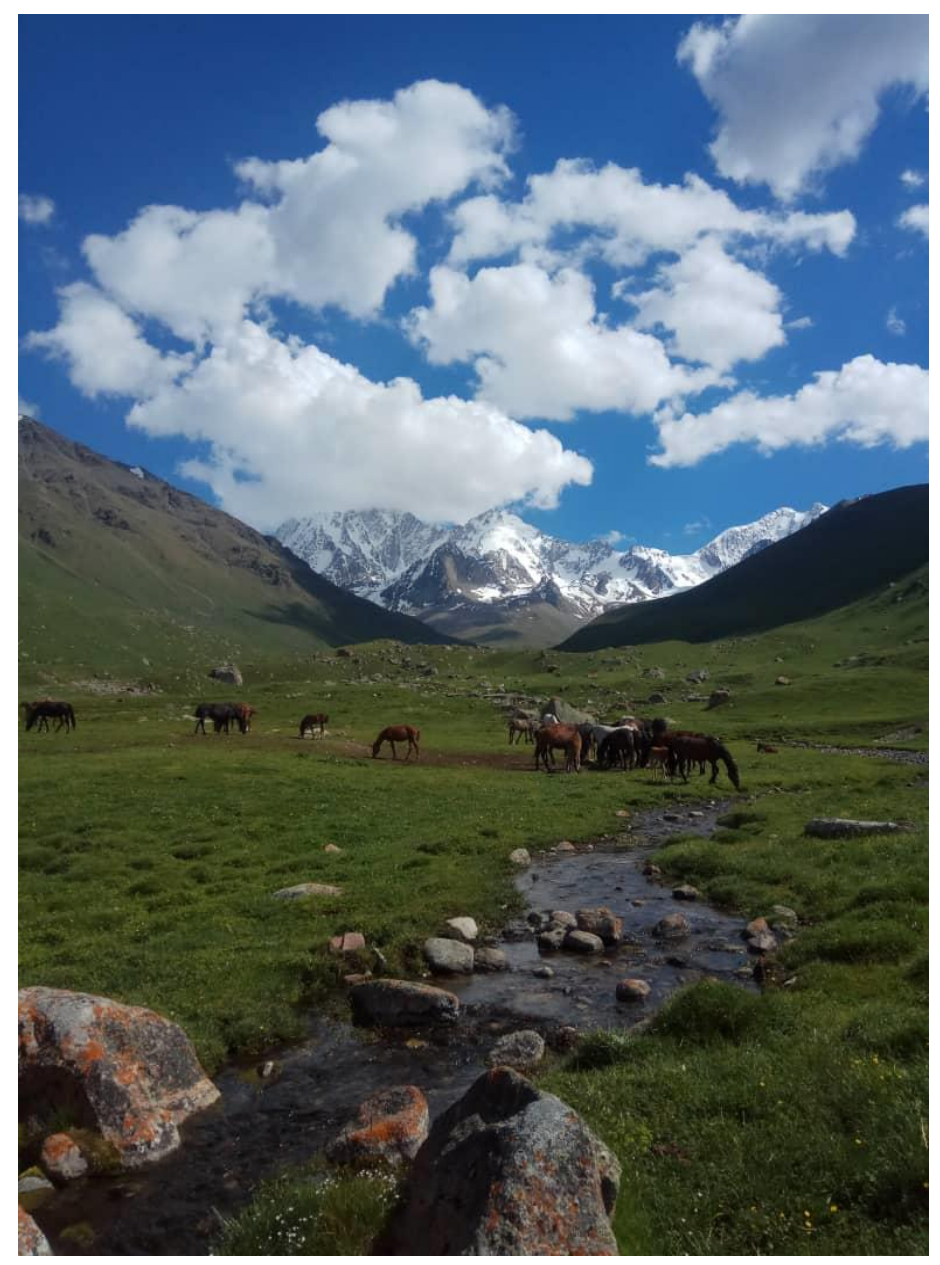

Horses on watering place at Chon Kemin jailoo, Kyrgyzstan. Summer 2020. Taalaibek Kudaiberdiev, Bishkek, Kyrgyzstan 